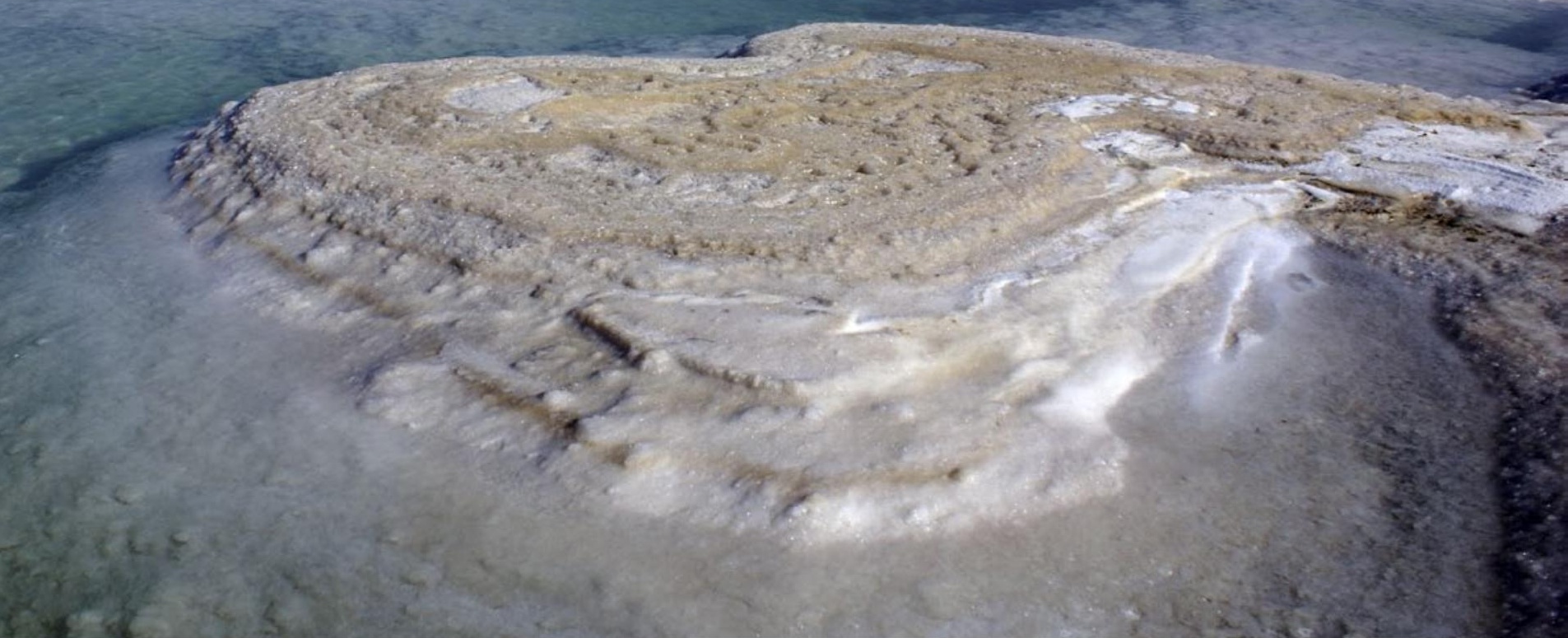

\title{
死海再生プロジェクト
}

\section{New life for the Dead Sea?}

イスラエルとヨルダンに接する死海は、近年湖面の低下が著しい。

そこで紅海から水路を引いて、縮小する死海を穌らせる計画が持ち上がっている。

この巨大土木プロジェクトは、周辺地域の水不足も軽減できるが、

計り知れない影響を多方面に及ぼす可能性がある。

Itay Reznik は死海の岩だらけの湖岸に 立ち、両腕を高く上げた。いつぱいに伸 ばした指先からさらに 1 メートル半上 空に、かつての船着き場がぶら下がって いる(13ページの写真参照)。Reznik は、 ネゲブ・ベン - グリオン大学 (イスラエ ル・ベールシェバ) で地質学を専攻する 大学院生。「私が博士課程の研究に取り かかった 2007 年には、この船着き場か ら船に乗ることができたのですよ」と話 す。現在の湖面は、宙ぶらりんの船着き 場から 3 メートル以上も下にある。
死海はイスラエルとヨルダンに接する 湖で、塩分濃度が非常に高く、地球の 表面で最も低い場所として知られてい る。年々低くなっている湖面は、50 年 間で 30 メートル近くも低下し、表面積 はこの 100 年間に 3 分の 1 近くも縮小 した。近年、そのペースが加速していて、 1 年で平均 1.2 メートルずつ低下してい る。Reznik や彼の指導教官で同大学の 地質学者Jiwchar Ganor とともにこの 地域をドライブしていると、その縮小ぶ りがよくわかる。死海の北西岸にあるエ
ン・フェシュカという自然保護区の淡水 泉には、1968 年と 1984 年の湖岸線を 示す小さな看板が立っている。今では、 1968 年の看板は湖岸から 2 キロメート ルも離れたところにあり、1984 年の看 板は、崩れかけた「海への階段」の横に わびしく立っている。現在、階段の先に 海はない。

死海から流れ出る川はないが砂漠に 位置するため、流入する水の量よりも 蒸発する水の量のほうが多い。かつて、 毎年 13 億立方メートルもあったヨルダ 
ン川からの流入淡水量は、現在は 1 億 立方メートル未満まで減少している。と いうのも、イスラエル、シリア、ヨルダ ンが、飲料水や農業用水として使用し ているからだ。そして、死海へ流入する 水の大半は、農業流去水や下水である。 さらに死海の南端では、イスラエルの Dead Sea Works 社とヨルダンの Arab Potash Company 社が、湖水を蒸発さ せてカリウムとマグネシウムを取り出 す事業を行っており、問題を悪化させ ている。

このままでは、死海はどんどん縮小し ていくだろう。そこで、紅海から全長 180 キロメートルの水路を建設して水 を引き、死海を蘇らせるプロジェクトが 提案され、世界銀行による評価を受けて いる。この水路は、運河かパイプライン、 あるいは両方を組み合わせたものが考 えられており、水力発電のエネルギーで 淡水化プラントを稼㗢させ、周辺地域に 毎年 8 億 5000 万立方メートルの飲料水 を供給できるという（下図「死海を救う」 参照)。これは、イスラエルで消費され ている飲料水の半分弱の量である。

紅海と死海を結ぶ運河計画が提案 されたのはこれが初めてではない。 1664 年、イエズス会のドイッ人学者 Athanasius Kircher が、各地を結ぶ輸
送用運河のネットワークの一部として 構想したのが最初といわれている。その 後も、同様の計画が何度も持ち上がって は立ち消えになった。1973 年のオイル ショック後にも、イスラエルが地中海と 死海を結ぶ運河に水力発電所を建設す ることを考えていた。

けれども近年、ヨルダンの飲料水不足 が深刻化してきたことや、共同で「平和 の水路」を建設したいというイスラエル、 ヨルダン、パレスチナ自治政府の願いか ら、紅海一死海水路計画が現実味を帯び てきた。3 か国の政府はこのプロジェク トのために共通の目標を立て、2005 年 には共同で世界銀行に㗢きかけて、プロ ジェクト実現の可能性と、環境に及ぼす 影響の調査を依頼した。世界銀行の水資 源管理と公衆衛生の専門家チームのリー ダーで、プロジェクトの調査プログラム を監督している Alex McPhail は、「こ こは、世界で唯一、イスラエル、ヨルダ ン、パレスチナ自治政府が共同で公的な プロジェクトに取り組んでいる場所なの です」という。

しかし、環境保護主義者はこのプロ ジェクトに懐疑的だ。イスラエル、ヨル ダン、パレスチナの環境保護団体で、テ ルアビブ、アンマン、ベッレヘムに支 部を置くFriends of the Earth Middle
East（FoEME）は、建設費数十億ドル といわれるこの水路が環境に及ぼす影 響を懸念している。水路は、紅海のアカ バ湾から最大で年間 20 億立方メートル の水を取り込むことになるが、アカバ湾 に生息する約 1000 種の魚類と 110 種 の造礁サンゴへの影響については不明 である。また、計画では水路はアラバ渓 谷を通るが、ここには希少動物ガゼルや ハイラックス、野ウサギが生息してい る。そのうえアラバ渓谷には活断層も 走っていて、地震で水道システムが破壊 される可能性もある。環境保護主義者 たちは、とにかく、莫大な費用がかか り、潜在的に有害なこのプロジェクトは 必要ないと主張する。彼らは、イスラエ ルとヨルダンが自国の水資源の保全に もつと力を入れれば、元どおりとはいわ ないまでも、少しはヨルダン川の状態を 回復できるはずだという。

一方、Reznik ら研究者たちは、さま ざまな問題を解決しょうと奔走してい る。彼らの調査結果は世界銀行が 2011 年に提出する最終報告書に盛り込まれ る。この報告書は、イスラエル、ヨルダン、 パレスチナ自治政府がプロジェクトを進 めるべきかどうか、そして、建設・運営 資金を調達できるかどうかの判断に役立 つだろう。

\section{死海を救う}

縮小の一途をたどる死海を救うため、紅海と死海を結ぶ水路の建設が計画 されている。さまざまなルートが検討されているが、死海の海抜は低く、 どのルートでも水は下に向かって流れることになるので、水力発電が可能 だ。その電力を利用して淡水化プラントを稼働させ、周辺地域に淡水を供 給することができる。
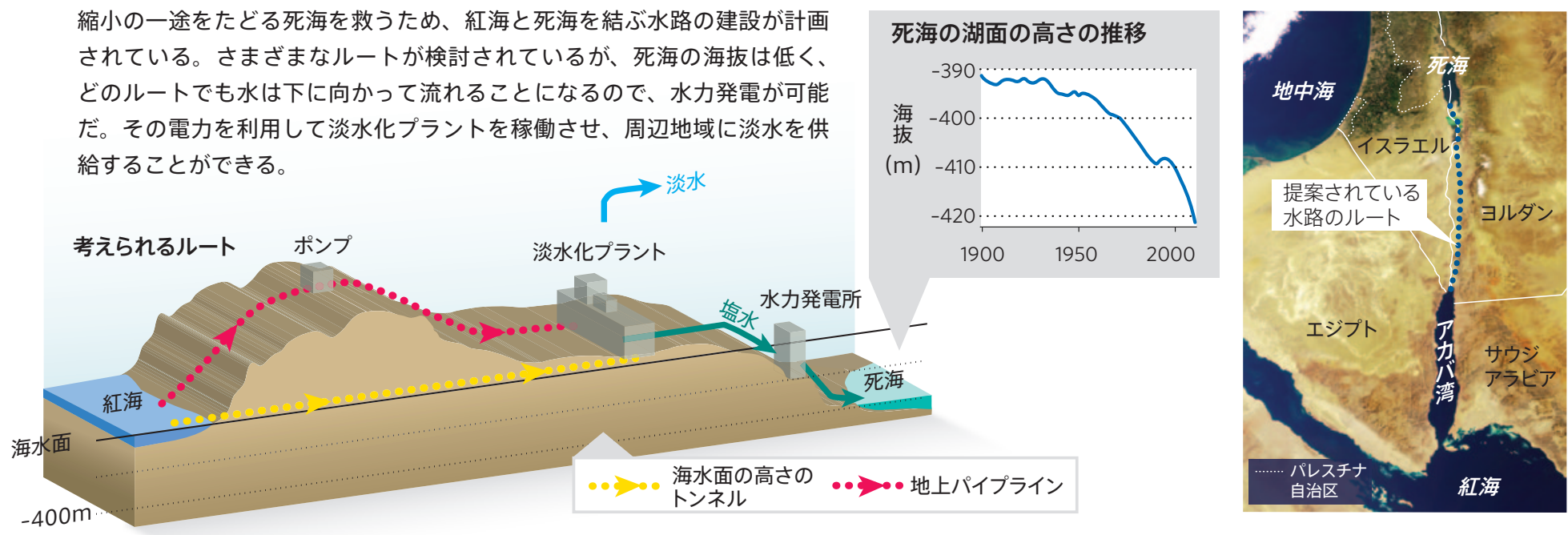


\section{期待と懸念}

死海が縮小すると湖底が露出してくる。 こうした土地は塩分濃度が高く、ほとん どの植物は成長することができない。か つては死海の湖岸に沿つて淡水泉があ り、ヤシの木などが生い茂るオアシスを 作っていたが、現在の涌出口は低い土地 に移動していて、湖岸の泥の中にある。 環境保護主義者たちは、オアシスの衰退 が渡り鳥に悪影響を及ぼすことを心配し ている。渡り鳥は、サハラ砂漠を渡る前 に、この地域のオアシスに立ち寄って体 を太らせていくからだ。また、干上がっ た土地に淡水が浸潤したため堆積物中の 塩の層が溶け、陥没穴が約 3000 個もで きている。

死海の縮小は、人間にも損害を与えて いる。死海周辺は観光地になっているだ けでなく、複数の農業共同体が形成され ている。死海の縮小が進んだため、ホテ ルの建設や娛楽施設・公共施設の整備が 中断し、陥没穴で道路や橋が壊され、農 業にも悪影響を及ぼしているのだ。

おそらく、死海が完全に消滅すること はないだろう。表面積が小さくなるにつ れ、塩分濃度が高くなり、蒸発が遅くな るからだ。イスラエル地質調査所（エ ルサレム）の Ittai Gavrieli 所長代行は、 提案されている水路が環境に及ぼす影響 を調べるモデル化研究チームを率いてい るが、死海は死なないでしょう」という。 しかし、この状沉が続くなら、現時点で 海抜マイナス 423 メートルの死海の湖 面は、さらに $100 \sim 150$ メートル低く なるだろうという。

ヨルダン渓谷庁（アンマン）の Mousa Jama'ani 事務総長によると、紅 海一死海水路は、環境へのさらなる打撃 を阻止するだけでなく、ヨルダンの水不 足を救うこともできるという。ヨルダン 周辺の湾岸諸国はヨルダンよりも淡水資 源は少ないが、石油を使って発電し、海 水を淡水化するプラントを稼㗢させてい る。「ここヨルダンには、石油も水もな いのです」と Jama'ani はいう。

紅海一死海水路の淡水化プラントは、
ヨルダンが切望する飲料水の供給源と なるだろう。「人口は増加の一途をた ぞっており、需要は高まるばかりなの に、水資源は限られているのです」と Jama'ani はいう。「我々にできることは 何でしょう？ 政府は国民に対して責任 を負っているのです」。

パレスチナ水資源庁（ラマラ）の Shaddad Attili 長官は、淡水化プラント はパレスチナにも水を供給することにな るという。パレスチナの水源は、ヨルダ ン川西岸地区の山岳帯水層と、ガザ地区 に水を供給する沿岸帯水層しかない。そ のうえ沿岸帯水層は、海水が侵入し下水 で污染されている。

$\ulcorner 1967$ 年以来、パレスチナ人はヨル ダン川流域に近づくことができません」 と Attili はいう。死海の北西岸を開発す ることも許されていない。Attili は、紅 海一死海プロジェクトで、イスラエルと の協力が合意できたのは大きな前進だと 考えている。イスラエル水資源庁のス ポークスマンである Uri Shor も同意見 だ。イスラエルは、飲料水の約 3 分の 1 をガリラヤ湖から、残りのほとんどを地 下带水層から得ている。また、 1 年に約 1 億 6500 万立方メートルの海水や塩分 濃度がやや高い水を淡水化している。こ れは、18 億立方メートルという国内水 消費量の約 9 パーセントに相当する量 だ。「このようなプロジェクトは国際協 力の足場となるため、我々にとっても有 益です」と Shor はいう。

2008 年には、米国、フランス、ス ウェーデンなど 8 か国から 1670 万ドル （約 15 億円）の援助を受けて、世界銀行 が、紅海一死海水路建設の可能性と社会 や環境に及ぼす影響を調査するプログラ ムに着手した。以後 18 か月間、水路の 最適な経路 (おそらくヨルダン領を通る ことになる)、その形状（運河、トンネル、 パイプライン、あるいはそれらの組み合 わせ)、取水口の種類、ポンプ場や淡水 化プラント、水力発電所の建設場所、淡 水化した水の割り当てなどについて検討 し、一連の中間報告書 ${ }^{1,2}$ を提出してきた。
世界銀行は最近、水路が紅海と死海に

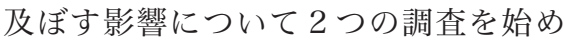
た。2009 年 10 月には FoEME からの 圧力を受けて「代替案の調査」を開始し、 英国、ヨルダン、イスラエルの専門家が、 トルコから水を引くパイプラインや、ヨ ルダン川の流量の回復など、紅海一死海 水路以外の選択肢を検討している。

水路建設に当たり、考慮すべき重要な 要素の 1 つに地震のリスクがある。ア ラバ渓谷に沿って走る死海断層は活発 な地震帯で、2つのプレートの境界線に なっている。世界銀行からの委託で行わ れた予備的な調査 ${ }^{1}$ によると、水路の運 用中に大地震が起きてポンプ場や淡水化 プラントが危険にさらされる可能性は大 きいという。しかし Gavrieli は、断層 の位置を特定し、水路や関連施設を巧妙 に設計すれば、そのような損害は未然に 防げるだろうという。「断層線の場所が わかっているなら、地震に備えればいい のです。耐震構造や免震構造にすること もできるでしょう」と彼はいう。

世界銀行の報告書では、そのほかのリ スクについても検討されている。例えば、 アカバ湾からポンプで水を吸い上げると 潮の流れが変わり、サンゴや海草を傷め てしまう可能性がある。また、水路から 海水が漏孔て、地下水を污染してしまう 可能性もある。アラバ渓谷では、生息す る野生動物への影響のほか、渓谷に点在 する古代の住居、水道、貯水池、銅の製 錬所、墓地などの遺跡も損傷を受けるお それがある。

さらに、イスラエルの不動産王 Yitzhak Tshuva は、この水路に沿って 公園、湖、滝、ホテル、植物園などが立 ち並ぶラスベガス式の「平和の谷」を建 設しょうと計画しており、アラバ渓谷の 生態系にとって大きな劦威になることが 懸念されている。

\section{死海に棲む生物}

紅海一死海水路は、死海そのものも変え てしまう可能性があり、長期的な影響は 不明である。「死海」という名に反して 
この湖には、塩而性の単細胞緑藻ドナリ エラ Dunaliella や赤い色をしたハロバク テリウム科の古細菌など、さまざまな微 生物が生息している。雨が多く、死海の 湖面が 2 メートルも上昇した 1992 年の ような年には、塩分濃度がわずかに低く なり、ドナリエラが繁茂する。このため、 新しい水路もドナリエラの繁茂を引き起 こす可能性がある。死海の塩分濃度は、 紅海の海水よりも、淡水化プラントの排 水よりも、はるかに高いからだ。

Gavrieli とへブライ大学 (イスラエ ル・エルサレム）の微生物学者 Aharon Oren が Dead Sea Works 社で行った実 験からは、塩分濃度が比較的低い水の流 入により藻が大発生することが示され た。その影響は、ヨルダン川に流れ込ん だリン肥料が、さらに死海に流入するこ とで増強されるだろう ${ }^{3}$ 。Gavrieli は、 大発生したドナリエラが古細菌の慨にな り、死海を赤く変色させるだろうという。 これを問題視するかどうかは、人によっ て違ってくる。「死海の水位が下がるこ とと、色が赤くなることと、どちらが大 きな問題でしょうか?」と Gavrieli は 問いかける。

あるいは、化学成分の変化により、死 海表面の水が白く変色するかもしれな い。現在、死海は宕亳（硫酸カルシウム の水和物）が過飽和状態になっている が、反応速度が非常に遅いのでどうにか 沈殿せずにすんでいる ${ }^{4}$ 。しかし、紅海 の水は死海の 10 倍の硫酸塩を含んでい るため、淡水化プラントから排出される 塩水が死海に流入すると、石膏は白い結 晶になって沈殿するだろう。Reznik と Ganor、そして Gavrieli は、死海の水と、 紅海の水を淡水化したときに出る排水を Dead Sea Works 社の 10 立方メートル のタンクの中で等量ずつ混ぜ、小さな白 い石膏の結晶が表面に現れてくるのを確 認した。Gavrieli によると、こうした変 化が、もつと大きい規模で、より長い期 間にどのような影響を及ぼすかは不明で あるという。石亳は湖底に沈むかもしれ ないし、結晶化して上層の水中に懸濁し、

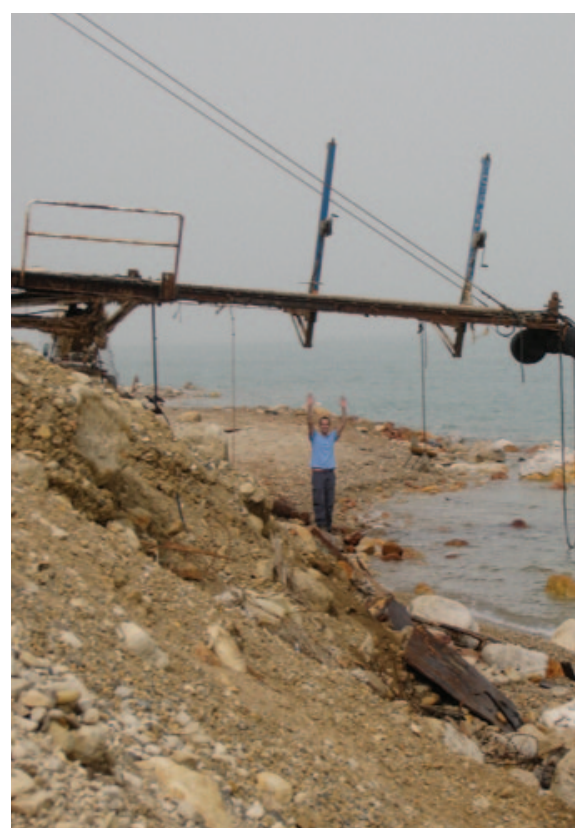

この船着き場は、2007 年には死海の湖面 と同じ高さだった。

湖を乳白色に変えるかもしれない。死海 の表面に結晶の膜ができれば、太陽光の 反射率が高くなり、蒸発速度はゆっくり になるかもしれない。しかし、石膏が湖 面に凝集し続けるなら、水中で光が散乱 し、水温が上がって、蒸発が盛んになる かもしれない。

Dead Sea Works 社と Arab Potash Company 社は、死海の運命のカギを 握っている。死海の水位低下の約 30 40 パーセントは、この 2 社の蒸発池に より説明できるからである。これに対し Dead Sea Works 社は、同社の蒸発池は、 1977 年に干上がった死海の南端を保全 することにより、地域住民を助けている と主張する。同社はまた約 1000 人の雇 用を生み出し、エン・ボケックでは大規 模なホテル群を経営している。

しかし、FoEME のイスラエル支部長 である Gidon Bromberg は、こうした 貢献を全く評価していない。彼によると、 カリウム製造会社は、死海の水を蒸発さ せてミネラルを得る方式から、高圧をか けて濾過膜に通す方式に切り替えること ができるはずだという。後者のほうが、 より多くの費用とエネルギーを必要とす
るが、蒸発する水の量を大幅に減らすこ とができる。

また、最近 FoEME の一連の研究から、 周辺の国々がコンポストトイレや真空式 トイレを導入したり、シャワーの水をト イレに再利用したりすれば、海水の淡水 化よりも少ない費用でヨルダン川の水を 毎年 4 億〜 6 億立方メートルも回復で きることが示された。FoEMEはまた、 持続可能な農業をより広く実践すること で水を保全できるだろうと主張する。

\section{苦渋の選択}

最終的には、切迫した真水の需要により 水路建設が推進されるだろう。Attili は、 イスラエル、ヨルダン、パレスチナ自 治政府の間にある、厳しい政治的緊張 を乗り越えて協力し合わなければなら ない、という。「ほかに選択肢はないの です」。次世代の国民のために、新しい 水源が必要なのだ。

現時点では、未来ははっきり見えない。 長く埃つぽい1 日の終わりに、Ganor と Reznik は車で死海の湖岸を上った。 そこには、赤い線が薄く残った岩が 1 つあった。1900～1913 年、英国人測 量士が死海の水位を測定したときに引い た線だ。現在の死海の湖面は、この線か ら 35 メートルも低いところにある。

このまま何もしなければ、状況はます ます悪くなるだろう。しかし、紅海一死 海水路は、現実の危険をもたらすだろ う。死海の縮小を食い止めるべきかどう かは、「2つの好ましくない選択肢のう ち、ましなほうを選ぶことなのです」と Gavrieli はいう。「ただ問題は、どちら がましなのかということです」。

(翻訳 : 三枝小夜子)

Josie Glausiusz はニューヨーク市在住のフリーランス のジャーナリスト。

1. Red Sea-Dead Sea Water Conveyance Study Program Feasibility Study. Options Screening and Evaluation Report. Executive Summary (Coyne et Bellier, 2009).

2. Red Sea-Dead Sea Water Conveyance Study, Environmental and Social Assessment. Preliminary Scoping Report. December 2008 (ERM/BRL/Eco Consult, 2008).

3. Oren, a. et al. J. Mar. Syst. 46, 121.131 (2004).

4. Reznik, I. J., Gavrieli, I. \& Ganor, J. Geochim. Cosmochim. Acta 73, 6218-6230 (2009). 